\title{
Edukasi Masyarakat Desa Kafoofoo di Kabupaten Muna Tentang Pencegahan Covid-19
}

\author{
Educating Kafoofoo Villagers District of Muna on Covid-19 Prevention
}

\author{
${ }^{1)}$ Ida Usman, ${ }^{2)}$ Mukhsar, ${ }^{3)}$ Bahriddin Abapihi, ${ }^{4)}$ Asrul Sani, ${ }^{5)}$ Wa Ode Sunaria, ${ }^{\text {*6) Baharuddin }}$ \\ 1) Jurusan Fisika, Fakultas Matematika dan Ilmu Pengetahuan Alam \\ 2,3,4,6)Jurusan Matematika, Fakultas Matematika dan Ilmu Pengetahuan Alam \\ ${ }^{5)}$ Jurusan Teknik Pertambangan, Fakultas Ilmu dan Teknologi Kebumian \\ Universitas Halu Oleo \\ Kampus Hijau Bumi Tridharma, Jl. H.E.A Mokodompit, Kendari 93232 \\ *email: baharuddinsaid@yahoo.com
}

DOI:

10.30595/jppm.v5i1.8782

Histori Artikel:

Diajukan:

$11 / 10 / 2020$

Diterima:

09/01/2022

Diterbitkan:

$18 / 02 / 2022$

\section{ABSTRAK}

COVID-19 adalah penyakit menular yang dapat menginfeksi banyak orang apabila tidak menerapkan protokol kesehatan yang ditetapkan oleh pemerintah. Penyakit ini telah menyebar dengan cepat ke berbagai daerah termasuk ke desadesa. Kegiatan pengabdian ini bertujuan mengedukasi masyarakat Desa Kafoofoo Kabupaten Muna dalam pencegahan penyebaran COVID-19. Tahapan pengabdian meliputi: pembekalan tim pelaksana, koordinasi dengan aparat desa, pengukuran tingkat pengetahuan masyarakat, dan edukasi pencegahan penyebaran COVID-19 melalui poster, alat peraga, dan penyuluhan kepada perwakilan warga. Hasil kegiatan edukasi menunjukkan bahwa tingkat pengetahuan masyarakat terhadap COVID-19 telah meningkat, yang ditandai dengan meningkatnya penggunaan masker di luar rumah.

Kata kunci: COVID-19; Desa Kafoofoo; Edukasi; Kabupaten Muna

\begin{abstract}
COVID-19 is an infectious disease in which many people can be infected when the health protocol being ignored. The disease has been spreading so fast in many places including rural areas. This community service program is aimed to educate villagers of Kafoofoo in Muna District to prevent the spread of COVID-19. The program parts involve: preparation of the team, coordination to officials in the village, knowledge assessment of the villagers, and education to villagers on COVID-19 prevention via poster, props, and counseling to villager representatives. The result of educating program shows that the levels of villager knowledge on COVID-19 have been upgraded and increasing as indicated by the increasing number of villagers using masks when away from home.
\end{abstract}

Keywords: COVID-19; Education; Kafoofoo Village; Muna District

\section{PENDAHULUAN}

Coronavirus Disease 2019 (COVID-19) adalah penyakit menular yang disebabkan oleh Severe Acute Respiratory Syndrome Coronavirus 2 (SARS-CoV-2) (Kemkes, 2020). Penyakit ini pertama kali terkonfirmasi di Kota Wuhan, Provinsi Hubei, Cina akhir tahun 2019. Dengan waktu yang singkat,
COVID-19 telah menjadi masalah kesehatan global yang kemudian ditetapkan sebagai pandemi oleh Badan Kesehatan Dunia WHO pada tanggal 11 Maret 2020. COVID-19 sudah menyebar di hampir seluruh negara, termasuk Indonesia. Kasus COVID-19 pertama di Indonesia terkonfirmasi di Provinsi DKI Jakarta (Gugus Tugas COVID, 2020). 
Hasil penelitian Park et al. (2020) merekomendasikan upaya mitigasi untuk meminimalkan dampak penyebaran COVID19 terhadap masyarakat. Berbagai program pengabdian telah dilakukan untuk mencegah meluasnya penularan penyakit ini. Wiratmo (2020) telah melakukan sosialisasi di suatu kawasan padat penduduk di Kota Semarang dengan memasang spanduk dan mengirim konten edukasi digital melalui WhatsApp. Demikian juga, Meri et al. (2020) telah mendistribusikan masker dan hand sanitizer pada warga sekitar kampus suatu perguruan tinggi di Tasikmalaya serta mengedukasi cara penggunaannya.

Dengan transmisi penularan dari manusia ke manusia, COVID-19 telah menjangkau seluruh kabupaten/kota di Provinsi Sulawesi Tenggara. Jumlah kasus dan/atau kematian COVID-19 di daerah ini semakin meningkat dan berdampak pada aspek ekonomi dan sosial masyarakat. Peningkatan jumlah kasus ini berlangsung cukup cepat dan menyebar ke berbagai daerah termasuk ke desa-desa.

Desa Kafoofoo adalah salah satu desa di Kecamatan Kontukowuna, Kabupaten Muna (BPS Muna, 2019). Sebagian masyarakat desa tersebut memiliki aktivitas dan mobilitas yang jangkauannya sampai ke daerah-daerah sekitarnya. Demikian juga, kunjungan keluarga atau orang lain dari daerah sekitar masuk ke desa tersebut sulit dihindari. Mengingat risiko penularan COVID-19 di Desa Kafoofoo, upaya pencegahan penyebaran penyakit harus dilakukan. Tujuan kegiatan pengabdian ini adalah memberikan edukasi kepada masyarakat Desa Kafoofoo dalam pencegahan penyebaran COVID-19.

\section{METODE}

Program edukasi pencegahan COVID-19 di Desa Kafoofoo dilaksanakan pada bulan Juli 2020, empat bulan setelah konfirmasi kasus COVID-19 pertama di Provinsi Sulawesi Tenggara (Dinkes Sultra, 2020). Kegiatan ini meliputi empat tahapan: (1) Pembekalan tim pelaksana pengabdian secara daring oleh dosen yang memahami materi tentang pencegahan penyebaran COVID-19; (2) Koordinasi dengan aparat desa untuk kelancaran kegiatan; (3) Pengukuran tingkat pengetahuan masyarakat Desa Kafoofoo melalui instrumen kuesioner; (4) Edukasi pencegahan COVID-19 di berbagai kalangan masyarakat. Program edukasi dilakukan melalui poster, alat peraga, dan penyuluhan. Rangkaian kegiatan tersebut dilaksanakan dengan menerapkan protokol kesehatan, seperti selalu menggunakan masker, menjaga jarak fisik minimal satu setengah meter, membawa hand sanitizer, tidak berjabat tangan, serta mencuci tangan sebelum dan sesudah keluar rumah.

\section{HASIL DAN PEMBAHASAN}

Desa Kafoofoo merupakan salah satu desa di Kecamatan Kontukowuna, Kabupaten Muna, Provinsi Sulawesi Tenggara (BPS Muna, 2019). Desa yang luasnya $12,36 \mathrm{~km}^{2}$ ini meliputi dua dusun, yaitu Dusun Kontuduy dan Dusun Ladambe. Jumlah penduduknya 669 jiwa dengan 134 kepala keluarga. Mayoritas pekerjaan penduduk Desa Kafoofoo adalah petani kebun dengan pendapatan per kapita masih di bawah rata-rata pendapatan penduduk Kabupaten Muna. Hal ini diduga menjadi penyebab rendahnya tingkat pendidikan masyarakat desa tersebut.

Kepedulian masyarakat terhadap kesehatan lingkungan sudah mulai muncul. Hal ini tergambar pada halaman pekarangan rumah yang bersih, teratur, dan indah. Sumber air bersih penduduk adalah sumur galian dengan layanan satu sumur dimiliki oleh tiga rumah. Mayoritas penduduk dengan pendapatan ekonomi bawah masih menggunakan WC umum dengan layanan dua rumah.

Meluasnya penyebaran COVID-19 ke berbagai daerah telah berdampak pada berbagai aspek kehidupan termasuk kepada masyarakat Desa Kafoofoo. Hal ini terkait dengan aktivitas dan mobilitas penduduk yang menimbulkan potensi penyebaran ke desa tersebut. Sebagian masyarakat Desa Kafoofoo memiliki mobilitas yang jangkauannya sampai ke daerah-daerah sekitarnya. Demikian juga, kunjungan orang luar daerah masuk ke desa tersebut sulit dihindari. Untuk itu, tim pelaksana pengabdian mengawali program edukasi dengan 
pembekalan dan koordinasi dengan aparat desa untuk kelancaran kegiatan (Gambar 1). Jumlah aparat Desa Kafoofoo adalah lima orang dan semuanya terlibat aktif dalam program edukasi ini.

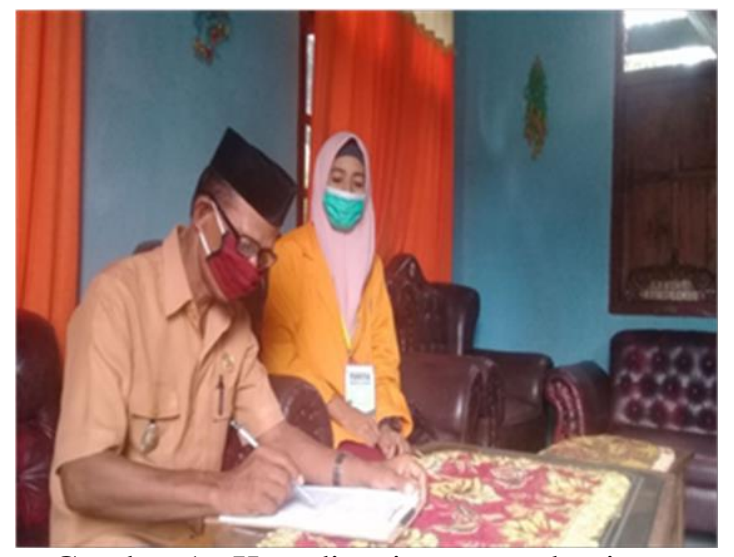

Gambar 1. Koordinasi program kegiatan dengan aparat desa (sumber foto: Sunaria)

Untuk mengukur tingkat pengetahuan masyarakat terhadap COVID-19 terlebih dahulu dilakukan pengedaran kuesioner kepada 32 warga sebagai responden. Kuesioner berisi pertanyaan-pertanyaan yang berkaitan dengan COVID-19. Pengedaran dan pengisian kuesioner dilakukan tim pelaksana dengan mendatangi perwakilan warga dan pelaksanaannya mengikuti protokol kesehatan yang ditetapkan pemerintah (Gambar 2). Responden yang dilibatkan sebagai sampel diharapkan mewakili populasi masyarakat Desa Kafoofoo.

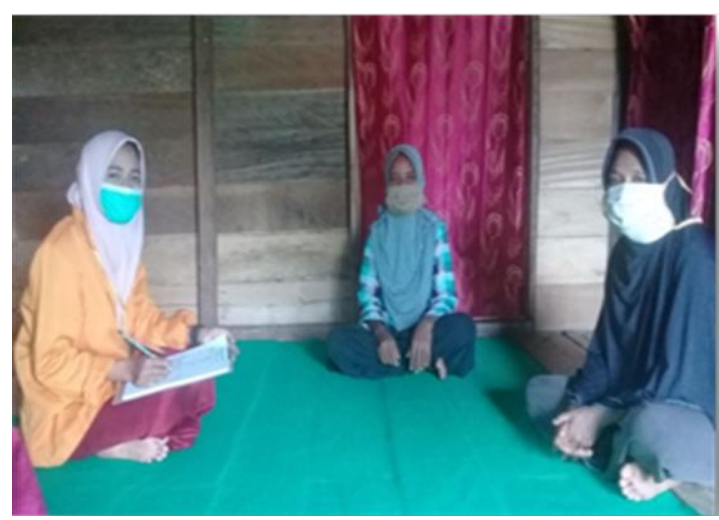

Gambar 2. Pengukuran tingkat pengetahuan masyarakat melalui pengisian kuesioner (sumber foto: Sunaria)
Karakteristik responden terdiri atas jenis kelamin, pekerjaan, pendidikan, umur, dan kategori aparat desa. Responden terdiri atas $46,88 \%$ laki-laki yang hampir berimbang dengan jumlah perempuan. Jumlah responden dengan pekerjaan petani $(56,25 \%)$ lebih banyak dibandingkan jumlah responden dengan jenis pekerjaan ASN, pedagang, pelajar, buruh, tukang ojek, dan ibu rumah tangga.

Jenjang pendidikan responden lebih banyak tamatan SD dan SMP/sederajat $(62,50 \%)$, sementara jenjang pendidikan lainnya proporsional dengan jumlah populasi. Berdasarkan kelompok umur, responden didominasi oleh kelompok orang dewasa dengan umur 31 tahun ke atas (71,88\%), sementara kelompok umur lainnya agak sedikit. Mayoritas responden bukan merupakan aparat desa $(84,38 \%)$.

Evaluasi terhadap isian kuesioner menghasilkan tiga kelompok kategori pengetahuan masyarakat Desa Kafoofoo terhadap COVID-19. Hasil pengelompokan menunjukkan bahwa tingkat pengetahuan masyarakat berada pada tingkat sedang (59,38\% responden). Di antara 32 responden, hanya 6 orang $(18,75 \%)$ yang memiliki pengetahuan baik dan selainnya termasuk tingkat pengetahuan buruk. Dengan demikian, program edukasi ini sudah tepat dilakukan terhadap masyarakat desa tersebut.

Edukasi pencegahan COVID-19 dilakukan tim pelaksana terhadap kelompokkelompok warga yang telah dirancang sebelumnya (Gambar 3). Kegiatan edukasi dilakukan melalui poster, alat peraga, dan penyuluhan. Penyuluhan terhadap kelompok warga yang biasa beraktivitas di luar rumah dilakukan di tempat pertemuan yang tersedia di Desa Kafoofoo. Sementara itu, edukasi terhadap warga yang memilih tinggal di rumah dilakukan dengan mendatangi rumah warga secara bergantian.

Penyuluhan merupakan salah satu metode yang dipilih tim pelaksana dalam program pengabdian ini karena telah terbukti meningkatkan pengetahuan warga yang menjadi partisipan. Sebagaimana yang dilakukan oleh Sammulia dan Suhaera (2019) 
yang menggunakan penyuluhan dalam program pencegahan dan pengendalian hipertensi dan asam urat telah berhasil meningkatkan pengetahuan warga dalam pemanfaatan tanaman obat keluarga.

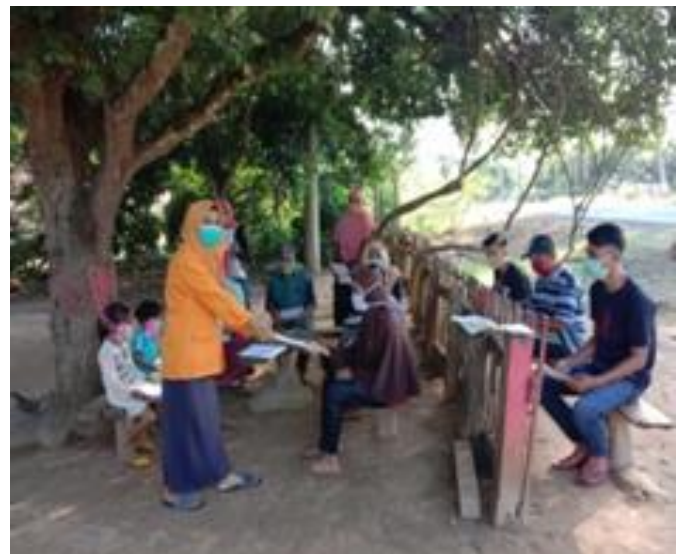

Gambar 3. Edukasi pencegahan COVID-19 di

Desa Kafoofoo (sumber foto: Sunaria)

Kegiatan edukasi terkait cara pencegahan penyebaran COVID-19 dilakukan terhadap warga Desa Kafoofoo dengan mengikuti protokol kesehatan. Beberapa protokol tersebut adalah selalu menggunakan masker, tidak berjabat tangan, menjaga jarak fisik minimal satu setengah meter, membawa hand sanitizer, serta mencuci tangan sebelum dan sesudah keluar rumah. Dalam program ini, tim pelaksana menggunakan alat peraga atau poster sebagai contoh yang dapat ditiru oleh masyarakat dalam beraktivitas sehari-hari. Pemasangan sejenis spanduk ini di tempat yang mudah di akses masyarakat juga telah dilakukan Wiratmo (2020) dalam sosialisasi pemutusan rantai penyebaran COVID-19 di Semarang.

Program edukasi yang melibatkan sebagian warga ini bertujuan melindungi diri dan keluarga dari penularan COVID-19. Warga desa yang mengikuti program ini juga diedukasi cara menggunakan masker dan cara mencuci tangan dengan air serta hand sanitizer. Kegiatan semacam ini juga telah dilakukan oleh Meri et al. (2020) di Tasikmalaya. Mengingat pelaksanaan program ini terbatas pada sebagian warga yang menjadi sasaran antara, perwakilan masyarakat yang mengikuti penyuluhan dapat meneruskan pengetahuan mengenai protokol kesehatan kepada warga lain di sekitarnya.

Rangkaian program edukasi ini dilaksanakan selama satu bulan. Hasil kegiatan pengabdian menunjukkan bahwa masyarakat Desa Kafoofoo sudah mulai menerapkan protokol kesehatan. Hal ini terlihat dari penggunaan alat pelindung diri saat beraktivitas di luar rumah. Di samping itu, tempat cuci tangan telah tersedia di beberapa tempat umum. Dengan demikian, perilaku dan aktivitas seluruh masyarakat selama pandemi COVID-19 dapat menyesuaikan dengan adaptasi kebiasaan baru.

\section{UCAPAN TERIMA KASIH}

Program edukasi pencegahan COVID-19 ini dibiayai oleh DIPA Universitas Halu Oleo tahun 2020. Untuk itu, tim pelaksana mengucapkan terima kasih kepada pimpinan Universitas Halu Oleo beserta jajarannya. Ucapan terima kasih juga disampaikan kepada Kepala Desa Kafoofoo beserta aparatnya atas kerja sama yang telah dilakukan.

\section{SIMPULAN}

Edukasi pencegahan COVID-19 telah dilakukan terhadap masyarakat Desa Kafoofoo Kabupaten Muna. Kegiatan edukasi dilakukan melalui poster, alat peraga, dan penyuluhan. Penyuluhan melibatkan perwakilan warga yang menjadi sasaran antara program edukasi ini. Hasil kegiatan pengabdian menunjukkan bahwa tingkat pengetahuan masyarakat terhadap COVID-19 telah meningkat.

\section{DAFTAR PUSTAKA}

BPS Muna (2019). Kecamatan Kontukowuna dalam angka 2019. Raha: Badan Pusat Statistik Kabupaten Muna.

Dinkes Sultra (2020). Data kewaspadaan COVID-19 per kabupaten/kota Provinsi Sulawesi Tenggara, update 26 Maret 2020. Kendari: Dinas Kesehatan Provinsi Sulawesi Tenggara. Diunduh dari: https://dinkes.sultraprov.go.id/infocovid-19-sultra/ tanggal 6 September 2020. 
Gugus Tugas COVID (2020). Protokol percepatan penanganan pandemi COVID-19. Jakarta: Gugus Tugas Percepatan Penanganan COVID-19.

Kemkes R.I. (2020). Pedoman pencegahan dan pengendalian coronavirus disease (COVID-19), (revisi ke-5). Jakarta: Kementerian Kesehatan Republik Indonesia.

Meri, Khusnul, Suhartati, R., Mardiana, U., \& Nurpalah, R. (2020). Pemberdayaan masyarakat dalam penggunaan hand sanitizer dan masker sebagai upaya preventif terhadap COVID-19. Bantenese Jurnal Pengabdian Masyarakat, 2(1), 26-33.

Park, M., Cook, A. R., Lim, J. T., Sun, Y., \& Dickens, B. L. (2020). A systematic review of COVID-19 epidemiology based on current evidence. Journal of Clinical Medicine, 9(967). http://dx.doi.org/10.3390/jcm9040967

Sammulia, S. F., \& Suhaera (2019). Pencegahan dan pengendalian hipertensi dan asam urat ringan melalui tanaman obat keluarga (TOGA). Jurnal Pengabdian dan Pemberdayaan Masyarakat, 3(2), 201-204.

Wiratmo, L. B. (2020). Sosialisasi pemutusan rantai penyebaran COVID-19 di Kelurahan Tlogosari Kulon Kota Semarang. Jurnal Pengabdian pada Masyarakat, 8(1), 57-65. 